\title{
Erratum to: Thermochemical Reaction of Lead Oxide with a Polytetrafluoroethylene Matrix
}

\author{
V. E. Rogov ${ }^{a}$ *, R. V. Kurbatov ${ }^{a}$, and L. A. Bokhoeva ${ }^{b}$ \\ a Baikal Institute of Nature Management, Siberian Branch, Russian Academy of Sciences, \\ Ulan-Ude, Buryatia, 670047 Russia \\ ${ }^{b}$ East Siberian State University of Technologies and Management, Ulan-Ude, Buryatia, 670033 Russia \\ *e-mail:rogov54v@mail.ru
}

Received December 23, 2019

DOI: $10.1134 / \mathrm{S} 1070427219120289$

The text in Funding section should be replaced by "The study was performed within the framework of the government assignment of Baikal Institute of Nature Management (Siberian Branch of Russian Academy of Sciences) and of the Ministry of Education and Science of the Russian Federation, project no. 9.7667.2017/BCh, 9.11221.2018/11.12."

The original article can be found online at https://doi.org/10.1134/S1070427219020071 